\title{
Potential of Inula racemosa root extract and its fractions to suppress root-knot nematode Meloidogyne incognita
}

\author{
Ramandeep Kaur $^{1}$, K. K. Chahal ${ }^{1 *}$, N. K. Dhillon ${ }^{2}$ and Urvashi Bhardwaj ${ }^{1}$ \\ ${ }^{1}$ Department of Chemistry, Punjab Agricultural University, Ludhiana- 141004 (Punjab), INDIA \\ ${ }^{2}$ Department of Plant Pathology, Punjab Agricultural University, Ludhiana- 141004 (Punjab), INDIA \\ *Corresponding author. E-mail: drkkchahal@pau.edu \\ Received: August 27, 2016; Revised received: February 8, 2017; Accepted: May 12, 2017
}

\begin{abstract}
Nematicidal potential of chloroform root extract of Inula racemosa and its fractions was investigated on egg hatching and mortality of root knot nematode Meloidogyne incognita. Egg masses and second stage juveniles $\left(\mathrm{J}_{2}\right)$ of $M$. incognita were exposed to different concentrations $\left(0.1-8.0 \mathrm{mg} \mathrm{ml}^{-1}\right)$ of $I$. racemosa root extract and its fractions. Observations on egg hatch were recorded on $1^{\text {st }}, 3^{\text {rd }}, 5^{\text {th }}, 7^{\text {th }}$ and $9^{\text {th }}$ day and those of mortality studies were recorded on $2^{\text {nd }}, 4^{\text {th }}, 6^{\text {th }}, 8^{\text {th }}$ and $10^{\text {th }}$ day, respectively. Significant mortality as well as egg hatch inhibition was observed for all the tested components at $5 \%$. The root extract was found to be most effective in controlling egg hatching as complete inhibition was observed at $8.0 \mathrm{mg} \mathrm{ml}^{-1}$ concentration on $1^{\text {st }}$ day of treatment and nonpolar fraction was most effective in causing mortality of $\mathrm{J}_{2}$ of $M$. incognita as $100 \%$ inhibition was observed at 6.0 and 8.0 mg $\mathrm{ml}^{-1}$ concentration on $2^{\text {nd }}$ day of treatment. Maximum inhibition of egg hatching was observed for root extract at 8.0 $\mathrm{mg} \mathrm{ml}^{-1}$ concentration and $100 \%$ mortality was observed for root extract as well as nonpolar fraction at the same concentration. The nonpolar fraction was most effective in causing mortality as maximum mortality was observed at 6.0 and $8.0 \mathrm{mg} \mathrm{ml}^{-1}$ concentration throughout the exposure time. Polar fraction was least effective among all the components both in egg hatch inhibition and $\mathrm{J}_{2}$ mortality of $M$. incognita. Both the activities showed concentrations as well as time dependence. Results show different role of tested components on egg hatching and mortality of root knot nematode. The root extract of $I$. racemosa and its fractions showed a potential to develop new nematicide.
\end{abstract}

Keywords: Asteraceae, Egg hatching, Juvenile, Root knot nematode, Soxhlet extraction

\section{INTRODUCTION}

Natural products comprise large and diverse group of substances obtained from various sources such as plants, marine organisms, bacteria and fungi. Many plant species produce biochemicals that protect them by killing or repelling the pest that feed on them. Plant based natural products are gaining importance as they minimizes the effects caused due to residual pesticides (environmental hazards, secondary pest outbreaks, resistance etc.). Out of several pathogenic organisms, soil borne pathogens are of major concern as they significantly reduce the yield and quality of vegetables crops. Soil borne pathogens are categorized under different phyla-bacteria, fungi and nematodes. Out of these nematodes especially root-knot nematodes are causing severe damage to vegetables crops resulting in decrease in production as well as quality of the crop. Root knot nematodes, Meloidogyne incognita is responsible for causing damage to 1700 plant species and are among the most destructive nematodes in agriculture; causing an estimated yearly crop loss of $\$ 157$ billion worldwide (Oka et al., 2000; Trudgill and Block, 2001, Singh et al., 2015), out of this $\$ 40.3$ is reported from India. It is the one of the major pest in vegetables and orchards. Although several synthetic pesticides and chemical fumigants are being used to control these soil borne parasites but most them are banned these days due to development of resistance in nematodes, which results into yield reductions of the crops (Noling and Becker, 1994). Moreover, their indiscriminate use causes serious damage to environment and human health. Agricultural production can be salvaged if these parasites are successfully combated. Therefore, scientists are developing alternative management techniques such as plant based chemicals, biological control agents, cropping systems soil amendments and judicious use of nematicides (Serfoji et al., 2010). Many scientists have carried out the research on plant extracts for the management of root knot nematodes. Chemicals produced by plants are potential source for the development of plant based pesticides. Several plant species are known to cause toxic affects against root knot nematodes (Onifade and Egunjobi, 1994; Nimbalkar and Rajurkar, 2009; Iruthaya and Devraj, 2011; Bharadwaj and Sharma, 2007) specifically members of family Asteracae (Chitwood, 2002; Moosavi, 2012). These plants or their parts (flowers, leaves, roots, seeds), either in crude form or as formulation, may be utilized as organic amendments 
or bio-pesticides (Perez et al., 2003).

Inula racemosa (Asteraceae) is an annual herbaceous plant found in North Western Himalayas (Khare, 2007), commonly known as pushkarmoola in Indian medicinal system. It is medicinally very important plant (Shabir et al., 2010) and used to treat many diseases in China since ancient times. Its seeds are aphrodisiac, roots are expectorant and are used to cure skin diseases and as adulterant for Sassurea costus roots (Sarin, 1996). This plant is also used by native Americans for treating tuberculosis (Moerman, 1986). Its roots are rich source of bioactive compounds. I. racemosa was found to show toxic effects against stored grain pests and many phytopathogenic fungi (Liu et al., 2006; Kataria and Chahal, 2013). Many investigators have reported the medicinal properties and biological activities of $I$. racemosa root extract, however little is known about the nematicidal effect of $I$. racemosa root extract and its fractions against $M$. incognita. However, toxicity of several other Inula species was reported against root knot nematodes as Inula viscosa powdered leaves and its extracts were found to have toxic effect against $M$. javanica (Oka et al., 2001).Therefore, in present research bioassay studies were undertaken to evaluate nematicidal properties of I. racemosa root extract and its bioactivity guided fractionation to assess its effect on second stage juveniles and eggs of $M$. incognita under laboratory conditions.

\section{MATERIALS AND METHODS}

Maintenance of pure culture of Meloidogyne incognita: The nematode $M$. incognita used in studies was identified by its characteristic perennial pattern. Pure culture was raised by single egg mass technique and multiplied on brinjal, a susceptible host for root knot nematode. For mass multiplication of $M$. incognita culture, the soil was autoclaved at 15 psi pressure and $121^{\circ} \mathrm{C}$ for at least $30 \mathrm{~min}$. The autoclaved soil was then filled in the pot. Three weeks old seedlings were transferred in to earthen pots containing sterilized soil and inoculated with freshly hatched $2^{\text {nd }}$ stage juveniles $\left(\mathrm{J}_{2}\right)$ collected from egg masses of pure culture. After sixty days of inoculation the egg masses were collected and were used for bioassay studies on egg hatching

Table 1. Effect of I. racemosa root extract, its non-polar and polar fraction on per cent egg hatch inhibition of M. incognita at different concentrations and durations.

\begin{tabular}{|c|c|c|c|c|c|c|c|c|}
\hline \multirow{2}{*}{ Particulars } & \multirow{2}{*}{$\begin{array}{l}\begin{array}{l}\text { Duration } \\
\text { (days) }\end{array} \\
\end{array}$} & \multicolumn{7}{|c|}{ Average $\%$ hatch inhibition at different concentrations $\left(\mathrm{mg} \mathrm{ml}^{-1}\right)$} \\
\hline & & $\mathbf{0 . 1}$ & 0.5 & 1.0 & 2.0 & 4.0 & 6.0 & 8.0 \\
\hline \multirow{5}{*}{ Root extract } & 1 & $\begin{array}{c}11.24 \\
(19.55)\end{array}$ & $\begin{array}{c}28.7 \\
(32.37)\end{array}$ & $\begin{array}{c}47.04 \\
(43.28)\end{array}$ & $\begin{array}{c}60.65 \\
(51.15)\end{array}$ & $\begin{array}{c}74.85 \\
(59.88)\end{array}$ & $\begin{array}{c}100 \\
(89.96)\end{array}$ & $\begin{array}{c}100 \\
(89.96)\end{array}$ \\
\hline & 3 & $\begin{array}{c}18.94 \\
(25.79)\end{array}$ & $\begin{array}{c}28.56 \\
(32.29)\end{array}$ & $\begin{array}{c}47.09 \\
(43.32)\end{array}$ & $\begin{array}{c}62.11 \\
(51.99)\end{array}$ & $\begin{array}{c}77.13 \\
(61.41)\end{array}$ & $\begin{array}{c}92.15 \\
(73.73)\end{array}$ & $\begin{array}{c}100 \\
(89.96)\end{array}$ \\
\hline & 5 & $\begin{array}{c}21.24 \\
(27.43)\end{array}$ & $\begin{array}{c}39.73 \\
(39.06)\end{array}$ & $\begin{array}{c}49 \\
(44.41)\end{array}$ & $\begin{array}{c}65.25 \\
(53.86)\end{array}$ & $\begin{array}{c}79.00 \\
(62.69)\end{array}$ & $\begin{array}{c}94.83 \\
(76.99)\end{array}$ & $\begin{array}{c}100 \\
(89.96)\end{array}$ \\
\hline & 7 & $\begin{array}{c}20.79 \\
(27.12)\end{array}$ & $\begin{array}{c}40.36 \\
(39.43)\end{array}$ & $\begin{array}{c}48.73 \\
(44.26)\end{array}$ & $\begin{array}{c}67.63 \\
(55.29)\end{array}$ & $\begin{array}{c}79.05 \\
(62.73)\end{array}$ & $\begin{array}{c}94.27 \\
(76.12)\end{array}$ & $\begin{array}{c}100 \\
(89.96)\end{array}$ \\
\hline & 9 & $\begin{array}{c}24.84 \\
(29.88)\end{array}$ & $\begin{array}{c}40.89 \\
(39.74)\end{array}$ & $\begin{array}{c}50.67 \\
(45.36)\end{array}$ & $\begin{array}{c}67.85 \\
(55.44)\end{array}$ & $\begin{array}{c}80.26 \\
(63.59)\end{array}$ & $\begin{array}{c}99.71 \\
(86.86)\end{array}$ & $\begin{array}{c}100 \\
(89.96)\end{array}$ \\
\hline \multirow{5}{*}{$\begin{array}{l}\text { Non-polar } \\
\text { fraction }\end{array}$} & 1 & $\begin{array}{c}11 \\
(19.35)\end{array}$ & $\begin{array}{c}23.97 \\
(29.29)\end{array}$ & $\begin{array}{c}37.05 \\
(37.48)\end{array}$ & $\begin{array}{c}45.44 \\
(42.36)\end{array}$ & $\begin{array}{c}54.83 \\
(47.752)\end{array}$ & $\begin{array}{c}68.94 \\
(56.11)\end{array}$ & $\begin{array}{c}85.51 \\
(67.59)\end{array}$ \\
\hline & 3 & $\begin{array}{c}18.67 \\
(25.58)\end{array}$ & $\begin{array}{c}34.76 \\
(36.11)\end{array}$ & $\begin{array}{c}41.06 \\
(39.83)\end{array}$ & $\begin{array}{c}48.99 \\
(44.41)\end{array}$ & $\begin{array}{c}61.86 \\
(51.84)\end{array}$ & $\begin{array}{c}73.69 \\
(59.12)\end{array}$ & $\begin{array}{c}84.09 \\
(66.45)\end{array}$ \\
\hline & 5 & $\begin{array}{c}21.12 \\
(27.35)\end{array}$ & $\begin{array}{c}32.99 \\
(35.04)\end{array}$ & $\begin{array}{c}49.87 \\
(42.05)\end{array}$ & $\begin{array}{c}52.48 \\
(46.40)\end{array}$ & $\begin{array}{c}64.75 \\
(53.56)\end{array}$ & $\begin{array}{c}75.89 \\
(60.57)\end{array}$ & $\begin{array}{c}86.12 \\
(68.11)\end{array}$ \\
\hline & 7 & $\begin{array}{c}22.61 \\
(28.38)\end{array}$ & $\begin{array}{c}41.77 \\
(40.24)\end{array}$ & $\begin{array}{c}53.22 \\
(42.73)\end{array}$ & $\begin{array}{c}55.07 \\
(47.89)\end{array}$ & $\begin{array}{c}65.61 \\
(54.08)\end{array}$ & $\begin{array}{c}74.46 \\
(59.62)\end{array}$ & $\begin{array}{c}89.87 \\
(71.41)\end{array}$ \\
\hline & 9 & $\begin{array}{c}19.66 \\
(26.23)\end{array}$ & $\begin{array}{c}43.72 \\
(41.37)\end{array}$ & $\begin{array}{c}55.91 \\
(43.30)\end{array}$ & $\begin{array}{c}57.44 \\
(49.26)\end{array}$ & $\begin{array}{c}63.32 \\
(52.70)\end{array}$ & $\begin{array}{c}76.85 \\
(61.22)\end{array}$ & $\begin{array}{c}90.51 \\
(72.02)\end{array}$ \\
\hline \multirow{5}{*}{ Polar fraction } & 1 & $\begin{array}{c}5.92 \\
(14.04)\end{array}$ & $\begin{array}{c}23.37 \\
(28.89)\end{array}$ & $\begin{array}{c}31.86 \\
(34.14)\end{array}$ & $\begin{array}{c}39.75 \\
(39.07)\end{array}$ & $\begin{array}{c}46.68 \\
(43.06)\end{array}$ & $\begin{array}{c}62.16 \\
(52.04)\end{array}$ & $\begin{array}{c}71.31 \\
(57.59)\end{array}$ \\
\hline & 3 & $\begin{array}{c}19.42 \\
(26.13)\end{array}$ & $\begin{array}{c}29.12 \\
(32.69)\end{array}$ & $\begin{array}{c}38.76 \\
(38.48)\end{array}$ & $\begin{array}{c}45 \\
(42.11)\end{array}$ & $\begin{array}{c}50.92 \\
(45.51)\end{array}$ & $\begin{array}{c}65.95 \\
(54.29)\end{array}$ & $\begin{array}{c}73.46 \\
(58.97)\end{array}$ \\
\hline & 5 & $\begin{array}{c}15.21 \\
(22.94)\end{array}$ & $\begin{array}{c}31.07 \\
(33.86)\end{array}$ & $\begin{array}{c}40.85 \\
(39.71)\end{array}$ & $\begin{array}{c}47.34 \\
(43.45)\end{array}$ & $\begin{array}{c}54.61 \\
(47.6)\end{array}$ & $\begin{array}{c}73.45 \\
(58.97)\end{array}$ & $\begin{array}{c}77.01 \\
(61.35)\end{array}$ \\
\hline & 7 & $\begin{array}{c}23.88 \\
(29.24)\end{array}$ & $\begin{array}{c}35.49 \\
(36.55)\end{array}$ & $\begin{array}{c}45.4 \\
(42.33)\end{array}$ & $\begin{array}{c}48.72 \\
(44.25)\end{array}$ & $\begin{array}{c}54.61 \\
(47.63)\end{array}$ & $\begin{array}{c}74.51 \\
(59.65)\end{array}$ & $\begin{array}{c}78.19 \\
(62.14)\end{array}$ \\
\hline & 9 & $\begin{array}{c}25.76 \\
(30.49) \\
\end{array}$ & $\begin{array}{c}35.71 \\
(36.68) \\
\end{array}$ & $\begin{array}{c}48.58 \\
(44.17) \\
\end{array}$ & $\begin{array}{c}46.74 \\
(43.11) \\
\end{array}$ & $\begin{array}{c}54.64 \\
(47.64) \\
\end{array}$ & $\begin{array}{r}74.46 \\
(59.63) \\
\end{array}$ & $\begin{array}{c}79.14 \\
(62.79) \\
\end{array}$ \\
\hline
\end{tabular}

Figures in parenthesis are arc sine transformed, CD 5\% A (Compounds) $=0.37, \mathrm{~B}($ Days $)=0.47, \mathrm{C}($ Concentrations $)=0.56, \mathrm{~A} \times \mathrm{B}$ (Interaction between compounds $\times$ days $)=0.82, \mathrm{~A} \times \mathrm{C}$ (interaction between compounds $\times$ concentrations $)=0.97, \mathrm{~B} \times \mathrm{C}$ (interaction between days $\times$ concentrations $=1.25, \mathrm{~A} \times \mathrm{B} \times \mathrm{C}$ (interaction between compounds, days and concentrations) $=2.18$ 
and mortality of $M$. incognita.

Procurement of raw material: The powdered roots of I. racemosa were subjected to Soxhlet extraction for 6-8 $\mathrm{hr}$ using chloroform as the solvent and was concentrated with a rotary vacuum evaporator at $40{ }^{\circ} \mathrm{C}$ to afford crude extract. The resulting chloroform extract was then partitioned into petroleum ether $\left(60-80{ }^{\circ} \mathrm{C}\right)$ and acetonitrile to have non-polar and polar fraction by liquid-liquid partitioning (Bahl and Bahl, 1992).

Preparation of test concentrations: Since, little work has been reported on the nematicidal activity of I. racemosa root extract and its fraction. Preliminary trials were conducted to standardize the range of concentrations to be used in trials and concentrations ranging from 0.1 to $8.0 \mathrm{mg} \mathrm{ml}^{-1}$ were found to be effective for carrying out nematicidal bioassay. The stock solution of concentration $8.0 \mathrm{mg} \mathrm{ml}^{-1}$ was prepared by dissolving $0.8 \mathrm{~g}$ of each component (root extract, non- polar and polar fraction) in $100 \mathrm{ml}$ of water along with Tween 80 as emulsifier. The serial dilutions were made using distilled water as required.
Three replications for each treatment were performed. As Tween 80 was not showing any difference in preliminary trails, therefore only water was used as negative control in further studies.

Bioefficacy: All bioassays were set up in laboratory conditions under controlled temperature and humidity $\left(27 \pm 2{ }^{0} \mathrm{C}\right.$ and $\left.70 \pm 1 \%\right)$. Egg hatch and mortality studies (second stage juveniles, $\mathrm{J}_{2}$ ) were conducted against root knot nematode $M$. incognita.

Hatching test: For extraction of egg masses the infected plants of brinjal were uprooted, carefully washed under tap water for removal of soil. The egg masses were isolated from roots and collected in Petri dishes containing water. Ten egg masses, with an average of 200-250 eggs per egg mass, were placed in $5 \mathrm{ml}$ of each concentration (0.1-8 mg ml $\mathrm{m}^{-1}$ ) and control (water only). The plates were covered with solid lid and wrapped with parafilm ${ }^{\circledR}$ and kept in an incubator. To avoid microbial contamination separate Petri dishes were used for each day. Number of hatched juveniles was counted on $1^{\text {st }}, 3^{\text {rd }}, 5^{\text {th }}, 7^{\text {th }}$ and $9^{\text {th }}$ day after incubation under light microscope. Each treatment was repli-

Table 2. Effect of I. racemosa root extract and its non-polar and polar fractions on percentage mortality of M. incognita at different concentrations and durations.

\begin{tabular}{|c|c|c|c|c|c|c|c|c|}
\hline \multirow{2}{*}{ Particulars } & \multirow{2}{*}{$\begin{array}{l}\begin{array}{l}\text { Duration } \\
\text { (days) }\end{array} \\
\end{array}$} & \multicolumn{7}{|c|}{ Average \% mortality at different concent)tration (mg ml } \\
\hline & & 0.1 & 0.5 & 1.0 & 2.0 & 4.0 & 6.0 & 8.0 \\
\hline \multirow[t]{14}{*}{ Root extract } & \multirow{2}{*}{2} & 15.9 & 32.8 & 40.3 & 48.1 & 58.5 & 64.2 & 100 \\
\hline & & $(23.49)$ & $(34.92)$ & $(39.39)$ & $(43.89)$ & $(49.87)$ & $(53.25)$ & $(89.96)$ \\
\hline & \multirow[b]{2}{*}{4} & 27.8 & 35.8 & 49 & 52.5 & 59.6 & 68.7 & 100 \\
\hline & & $(31.81)$ & $(36.73)$ & $(44.41)$ & $(46.41)$ & $(50.51)$ & $(55.83)$ & $(89.96)$ \\
\hline & \multirow[b]{2}{*}{6} & 38.3 & 49.0 & 53.8 & 56.2 & 60.4 & 75.0 & 100 \\
\hline & & $(38.22)$ & $(44.41)$ & $(47.160)$ & (48.54) & $(50.86)$ & $(58.70)$ & (89.96) \\
\hline & \multirow{2}{*}{8} & 47.2 & 59 & 66.7 & 75.0 & 81.0 & 86.7 & 100 \\
\hline & & $(43.38)$ & $(50.165)$ & $(54.73)$ & (59.97) & $(64.13)$ & $(68.58)$ & (89.96) \\
\hline & \multirow{2}{*}{10} & 59.0 & 75.6 & 85 & 100 & 100 & 100 & 100 \\
\hline & & $(50.16)$ & $(60.37)$ & (67.19) & (89.96) & (89.96) & (89.96) & (89.96) \\
\hline & \multirow{2}{*}{2} & 25.9 & 30.6 & 42.7 & 45.3 & 55.8 & 100 & 100 \\
\hline & & $(30.58)$ & $(33.57)$ & $(40.78)$ & $(42.32)$ & $(48.31)$ & (89.96) & (89.96) \\
\hline & \multirow{2}{*}{4} & 28.9 & 37.9 & 45.0 & 53.1 & 60.7 & 100 & 100 \\
\hline & & $(32.51)$ & (37.98) & $(42.11)$ & (46.76) & $(51.16)$ & (89.96) & (89.96) \\
\hline \multirow{10}{*}{$\begin{array}{l}\text { Non-polar } \\
\text { fraction }\end{array}$} & \multirow{2}{*}{6} & 35.5 & 44.2 & 58.2 & 66.2 & 72.1 & 100 & 100 \\
\hline & & $(36.56)$ & $(41.65)$ & (49.69) & (54.43) & (58.09) & (89.96) & (89.96) \\
\hline & \multirow{2}{*}{8} & 40.2 & 52.5 & 75.0 & 81.7 & 93.4 & 100 & 100 \\
\hline & & (39.02) & $(46.41)$ & (59.97) & $(64.65)$ & $(75.08)$ & (89.96) & (89.96) \\
\hline & \multirow{2}{*}{10} & 100 & 100 & 100 & 100 & 100 & 100 & 100 \\
\hline & & (89.96) & (89.96) & (89.96) & (89.96) & (89.96) & (89.96) & (89.96) \\
\hline & \multirow{2}{*}{2} & 0 & 0 & 0 & 25.0 & 30.0 & 50.0 & 90.0 \\
\hline & & $(0.18)$ & $(0.18)$ & $(0.18)$ & (29.99) & (33.21) & (44.79) & (71.54) \\
\hline & \multirow{2}{*}{4} & 10.8 & 22.4 & 28.9 & 30.2 & 42.0 & 55.3 & 92.1 \\
\hline & & (19.18) & $(28.24)$ & $(32.51)$ & (33.19) & $(40.38)$ & $(48.02)$ & (73.61) \\
\hline \multirow{6}{*}{ Polar fraction } & \multirow[b]{2}{*}{6} & 15.4 & 25.6 & 39.2 & 43.5 & 50.2 & 61.5 & 92.9 \\
\hline & & (23.09) & $(30.38)$ & $(38.75)$ & (41.25) & (45.09) & $(51.63)$ & (74.52) \\
\hline & \multirow{2}{*}{8} & 30.0 & 49.9 & 50.0 & 67.2 & 69.1 & 70.4 & 95.0 \\
\hline & & $(33.61)$ & $(44.93)$ & $(44.98)$ & (55.04) & $(56.21)$ & $(57.01)$ & (77.05) \\
\hline & \multirow{2}{*}{10} & 45.0 & 50.2 & 70.2 & 80.3 & 85.7 & 90.0 & 100 \\
\hline & & $(42.11)$ & $(45.09)$ & $(56.89)$ & $(63.41)$ & $(67.75)$ & $(71.54)$ & (89.96) \\
\hline
\end{tabular}

Figures in parenthesis are arc sine transformed, CD 5\% A (Compounds) $=0.75, \mathrm{~B}($ Days $)=0.97, \mathrm{C}($ Concentrations $)=0.11, \mathrm{~A} \times \mathrm{B}$ (Interaction between compounds $\times$ days $)=0.167, \mathrm{~A} \times \mathrm{C}$ (interaction between compounds $\times$ concentrations $)=0.19, \mathrm{~B} \times \mathrm{C}$ (interaction between days $\times$ concentrations $)=0.25, \mathrm{~A} \times \mathrm{B} \times \mathrm{C}$ (interaction between compounds, days and concentrations) $=0.44$ 


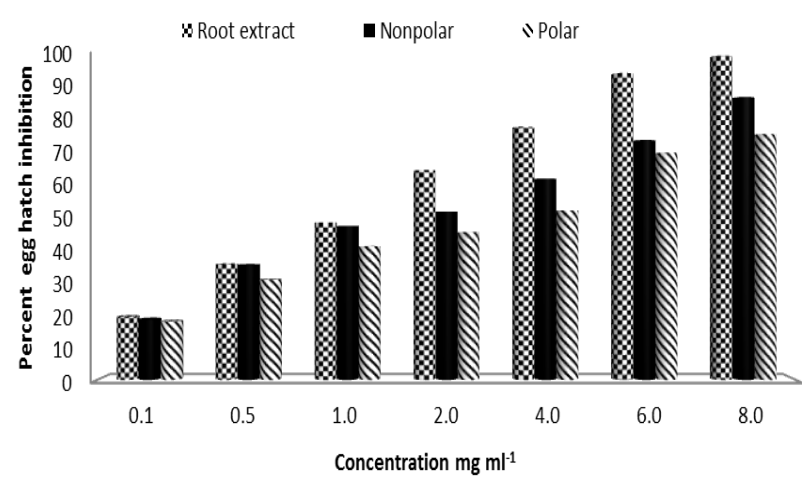

Fig. 1. Comparative study of I. racemosa root extract and its fractions on average egg hatch inhibition of $M$. incognita exposed to different concentrations.

cated thrice. The percentage inhibition was calculated by the formula (Chahal et al., 2016) and mean of three replications were presented (Table 1).

Mortality test: For mortality test, egg masses were handpicked using sterilized forceps from heavily infected roots. These egg masses were washed in distilled water, placed in 15 mesh sieve $(8 \mathrm{~cm}$ in diameter) containing crossed layers of tissue paper to obtain freshly hatched juveniles. After complete hatching, nematodes were collected in a beaker and allowed to settle down. Excess water was decanted off. The number of nematodes juveniles was adjusted to $100 \mathrm{~J}_{2} / \mathrm{ml}$ and number was counted under microscope. Counted number of juveniles were transferred to Petri dishes containing each concentration of test solution as well as control. Number of dead/alive nematodes was counted on $2^{\text {nd }}, 4^{\text {th }}, 6^{\text {th }}, 8^{\text {th }}$ and $10^{\text {th }}$ day of exposure. The plates were covered with solid lid and wrapped with parafilm ${ }^{\circledR}$ and kept in an incubator. The nematodes were considered dead if found motionless when probed with fine needle. After the last count, the inactive juveniles were maintained in distilled water for 24 hrs to observe their survival. The percent mortality was calculated (Chahal et al., 2016) using the formula and average mortality at a particular concentration was presented (Table 2).

Statistical analysis: Per cent egg hatch inhibition and per cent mortality data was subjected to statistical analysis using the factorial completely randomized design (CRD) statistical package. The critical differences in main effects i.e. compounds, concentrations and days as well as in their interactions were tested at $\mathrm{P}=0.05$.

\section{RESULTS AND DISCUSSION}

Egg hatching studies: The studies conducted on the I. racemosa root extract and its fractions inhibited egg hatching of $M$. incognita (Table 1). The maximum inhibition was observed at $0.8 \mathrm{mg} \mathrm{ml}^{-1}$ concentration for all the tested components. All the three components evaluated for their nematicidal efficacy were found to significantly $(5 \%)$ reduce egg hatching of $M$. incognita as compared to control (water only). Maximum hatch

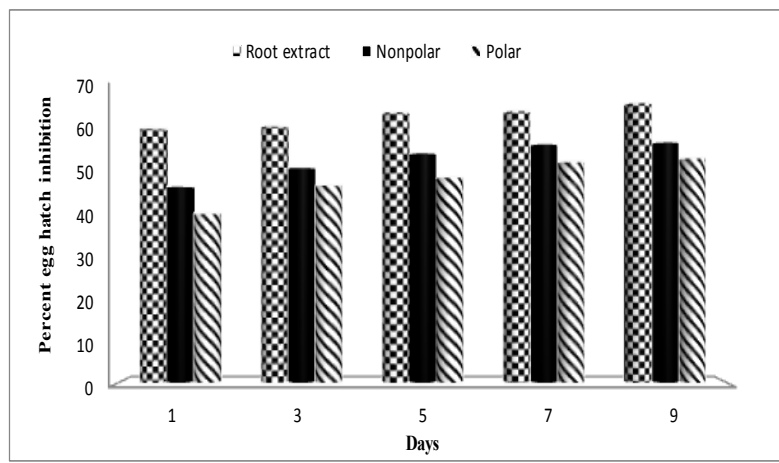

Fig. 2. Comparative study of I. racemosa root extract and its fractions on average egg hatch inhibition of $M$. incognita w.r.t. duration.

inhibition was observed in root extract at $0.8 \mathrm{mg} \mathrm{ml}^{-1}$ where even at the lowest duration of $24 \mathrm{hrs}$ egg hatching was completely inhibited. Minimum egg hatch inhibition was observed at lowest concentration of 0.1 $\mathrm{mg} \mathrm{ml} \mathrm{m}^{-1}$, where $11-24 \%$ decrease was observed in hatch inhibition of $M$. incognita. Egg hatching was inhibited in other concentration in the order of $0.1<0.5<1.0<2.0<4.0<6.0<8.0 \mathrm{mg} \mathrm{ml}^{-1}$ indicating that reduction in egg hatch was concentration dependent. The studies on the effect of duration (1, 3,5,7,9 days) revealed that hatching decreased from $1^{\text {st }}$ to $9^{\text {th }}$ day. Percent egg hatch inhibition was higher when the egg masses were exposed to longer duration (Fig. 1). Of the three components evaluated $I$. racemosa root extract and its fractions, root extract was found to be most effective at all the duration followed by non polar and polar fractions. Hence the order of activity was:Root extract $>$ Non-polar $>$ Polar fraction. Percent egg hatch inhibition by root extract ranged from $60-70$ $\%$ at different durations while in non-polar fraction the inhibition was found to be between 40-60\% and in polar 40-50 \% respectively (Fig. 2).

Mortality: The mortality of $I$. racemosa root extract and its fractions revealed that juvenile mortality increased with increase in exposure time and concentration and mortality differed significantly among different concentrations and exposure times (Table 2). Only $15.9 \%$ mortality occurred at $0.1 \mathrm{mg} \mathrm{ml}^{-1}$ on $2^{\text {nd }}$ day and increased to $59 \%$ on $10^{\text {th }}$ day, while at $0.5 \mathrm{mg}$ $\mathrm{ml}^{-1}$ concentration $32.8 \% \mathrm{~J}_{2}$ mortality was observed on $2^{\text {nd }}$ day which increased upto $75.6 \%$ on $10^{\text {th }}$ day of exposure. Maximum mortality was observed at $8.0 \mathrm{mg}$ $\mathrm{ml}^{-1}$ of root extract and non-polar fraction where complete mortality was observed on $2^{\text {nd }}$ day of exposure. Significant difference $(5 \%)$ in $\mathrm{J}_{2}$ mortality was observed at different concentrations for root extract and the same effect was observed for non-polar and polar fractions. Nonpolar fraction and root extract were significantly at par at $0.5 \mathrm{mg} \mathrm{ml}^{-1}$ where $\mathrm{J}_{2}$ mortality was observed between $30-50 \%$. In non polar fraction maximum mortality was observed for all the concentrations on $10^{\text {th }}$ day and for all the days at 6.0 and $8.0 \mathrm{mg} \mathrm{ml}^{-1}$ 


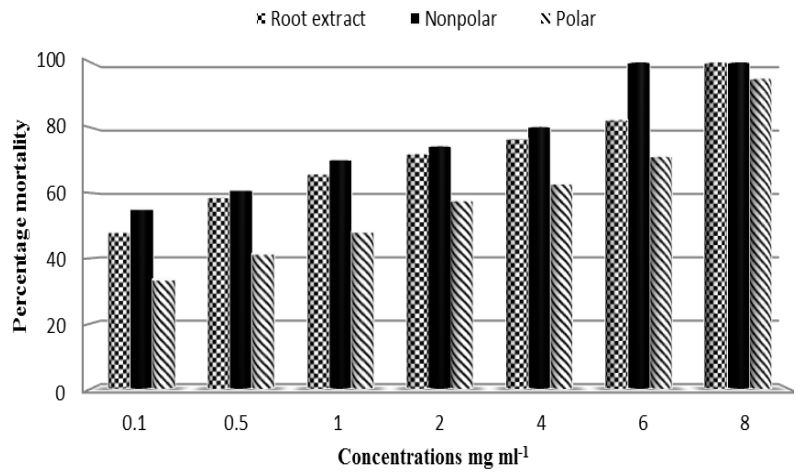

Fig. 3. Comparative study of I. racemosa root extract and its fractions on percent mortality of juveniles of M. incognita exposed to different concentrations.

concentrations. Polar fraction was found to be least effective as no mortality was observed at lower concentrations $\left(0.1-1.0 \mathrm{mg} \mathrm{ml}^{-1}\right)$ on $2^{\text {nd }}$ day of exposure. On comparing the average mortality with duration (Fig. 3) and concentration (Fig. 4), all the three components show linear increase in number of days and concentrations. Therefore, the order of effectiveness against $\mathbf{J}_{2}$ mortality is as follows: Non-polar $>$ Root extract $>$ Polar fraction.

In vitro evaluation of nematicidal properties of $I$. racemosa root extract and its fractions showed significant reduction in egg hatch count as well as enhanced mortality of second stage juveniles of $M$. incognita. Numbers of botanical plants and their constituents have been reported to possess nematicidal activity against root knot nematodes (Renco et al., 2014). Adegbite (2011) reported egg inhibitory effect of several indigenous plant extracts (Azadirachta indica, Chromolaena odorata, Nicotiana tabucum, Carica papaya, Cannabis sativa, Cassia alata and Vernonia amygdalina)against $M$. incognita. The nematicidal activity of essential oils extracted from several species(Calendula maritima, Calendula officinalis, Calendula suffruticosa, Crysanthemum coronarium and Crysanthemum segetum) of family Asteracae against $M$. artiellia has been investigated and the strongest nematicidal activity was exhibited by the essential oil obtained from the flower heads of Chrysanthemum coronarium (Perez et al., 2003). However very less reports are available on nematicidal properties of I. racemosa root extract and its fractions. Out of the three components tested, I. racemosa root extract was found to be most active as egg hatch inhibitor. The chemicals present in the plant extracts either affected the embryonic development or killed the eggs or even dissolved the egg masses. The egg hatch inhibitory effect of root extract might be due to permeability of egg shells of $M$. incognita to the compounds present in extract which are toxic to the developing juveniles. The plant extracts contained alkaloids, flavonoids, sesquiterpenoids, saponins, amides including benzamide and ketones that singly and in combination inhibited hatching (Adegbite, 2003; Goswamiand Vi-

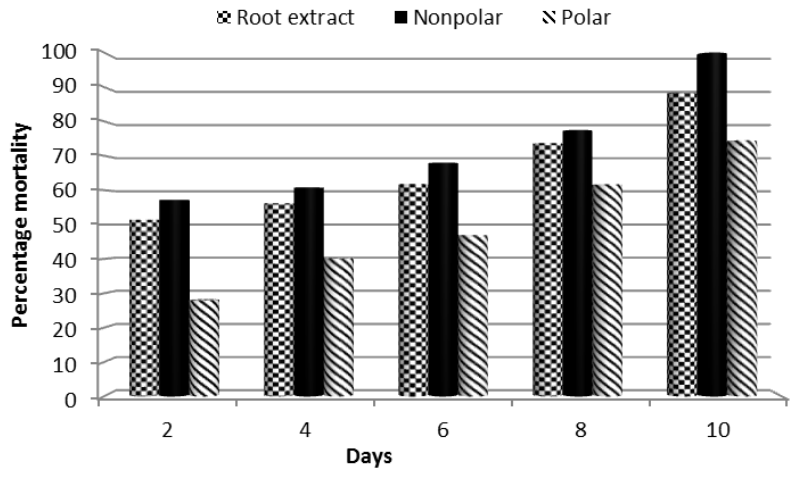

Fig. 4. Comparative study of I. racemosa root extract and its fractions on percent mortality of juveniles of $M$. incognita w.r.t time.

jayalakshmi, 1986; Chitwood, 2002). The nematicidal properties of $I$. viscosa leaf extract and its formulations have been reported against $M$. javanica (Oka et al., 2001; Oka et al., 2006) which was found to be due to the presence of some pharmacologically active compounds (Ulubelen et al., 1987; Wollenweber et al., 1991) including sesquiterpenes, sesquiterpene acids (Marongiu et al., 2003), azulenes, lactones, flavonoids and essential oils (Lauro and Rolih, 1990). Number of compounds with nematicidal activity had been isolated from species in family Asteracae (Chitwood, 2002; Gommers, 1981), out of these major compounds are sesquiterpenelactones which are very well documented for their biological activities (Hong et al., 2007). Sesquiterpenelactones isolated from different plant species have been known to show nematicidal, plant growth regulatory, antifungal and insecticidal properties (Datta and Saxena, 2001; Barrero et al., 2000; Liu et al., 2006; Ma et al., 2013, Wu et al., 2016). Chemical profiling of the root essential oil of I. racemosa showed the presence of mainly sesquiterpenes $(60 \%)$, and other minor constituent were apiotaxene (22\%) and phenylacetonitrile (2\%) (Bokadia et al., 1986). Jamna et al. (2012) reported the presence of tannins, sterols and alkaloids and absence of triterpenoids and flavonoids in the roots of I. racemosa. The sesquiterpenelactones isolated from the roots of $I$. racemosa are mostly eudesmanolides with specific alantolide skeleton (Kalsi et al., 1989; Wang et al., 2000). The roots of I. racemosa are rich in sesquiterpenelactones (Seca et al., 2014; Goyal et al., 1990), specifically those containing $\alpha$-methylene- $\gamma$-lactone moieties.

In present study, non-polar fraction of I. racemosa root extract was found to be most lethal against $\mathrm{J}_{2}$ of $M$. incognita, whereas root extract was found to be more effective as egg hatching inhibitor, depicting larvicidal properties of non-polar fraction and ovicidal properties of root extract. The polar fraction was found to be least active among all the tested components, showing that less polar components were more active and the results are in accordance with the findings of Barrero et al., (2000) who reported low toxicity of polar as compared 
to non-polar sesquiterpenelactones against fungus, Cunningham ellaechinulata. Alantolactone and isoalantolactone isolated from the roots of I. racemosa were found to be effective against juveniles of $M$. incognita. In the present study exposure of the nematode juveniles to $1100 \mu \mathrm{g} \mathrm{ml}^{-1}$ of alantolactone for $24 \mathrm{hrs}$ caused a mortality of $97 \%$ relative to the control. Sesquiterpenoid lactones having $\alpha$-methylene- $\gamma$-lactone moiety were found to be more effective than other compounds devoid of this moiety. Alantolactone was found to be most effective among all the tested components (Mahajanet al., 1986). Alantolactone has also been known to possess anthelmintic activity (Bourrel et al., 1993).

I. racemosa root extract and its non-polar and polar fractions showed nematicidal properties against $M$. incognita. Root extract was found to be most active $(100 \%)$ as egg hatch inhibitor at $8 \mathrm{mg} \mathrm{ml}^{-1}$ showing ovicidal properties and non-polar fraction at 6 and 8 $\mathrm{mg} \mathrm{ml}^{-1}$ against $\mathrm{J}_{2}$ of $M$. incognita showing larvicidal properties. Nematicidal properties of I. racemosa root extract and its fractions might be due to the presence of sesquiterpenelactones, (alantolactone and isoalantolactone) especially those containing $\alpha$-methylene- $\gamma$ lactone moiety. The studies will be needed to test the efficacy of extract and its fractions under field conditions. Further studies are required to isolate bioactive compounds from this extract responsible for egg hatch inhibition as well as mortality of $M$. incognita so that commercial nematicide can be developed for its practical use throughout the world.

\section{ACKNOWLEDGEMENTS}

The first author would like to thank Ministry of Minority Affairs, Government of India for providing Maulana Azad National Fellowship for Ph.D.

\section{REFERENCES}

Adegbite, A. A. (2011). Effects of some indigenous plant extracts as inhibitors of egg hatch in root-knot nematode (Meloidogyne incognita race 2). Am. J. Exp. Agric., 1(3): 96-100

Adegbite, A. A. (2003). Comparative effects of carbofuran and water extract of Chromolaena odorata on growth, yield and food components of root-knot nematodeinfested soybean (Glycine max (L.) Merrill). Ph.D. Dissertation. University of Ibadan, Ibadan, Nigeria.

Bahl, B. S. and Bahl, A. (1992). A text book of organic chemistry. $13^{\text {th }}$ ed. S chand and Company Ltd: New Delhi.

Barrero, A. F. U., Oltraa, J. E., Alvarez, M., Raslan, D. S., Saude, D. A. and Akssirad, M. (2000). New sources and antifungal activity of sesquiterpene lactones. Fitoterapia, 71: 60-64

Bharadwaj, A. and Sharma, S. (2007). Effect of some plant extracts on the hatch of Meloidogyne incognita eggs. Int. J. Bot., 3: 312-316
Bokadia, M. M., Macleod, A. J., Mehta S. C., Mehta B. K. and Patel, H. (1986). The essential oil of Inula racemosa. Phytochemistry 25(12): 2887-2888

Bourrel, C., Vilarem, G. and Perineau, F. (1993). Chemical analysis, bacteriostatic and fungistatic properties of the essential oil of elecampane (Inula helenium L.). J. Essent. Oil Res., 5:411-417

Chahal, K. K., Singh, B., Kataria, D. and Dhillon, N. K. (2016). Nematotoxicity of lemongrass oil, citral and its derivatives against Meloidogyne incognita. Allelopathy J., 39(2): 219-232

Chitwood, D. J. (2002). Phytochemical based strategies for nematode control. Annu. Rev.Phytopathol., 40: 221-249

Datta, S. and Saxena, D. B. (2001). Pesticidal properties of parthenin (from Parthenium hysterophorus) and related compounds. Pest Manag.Sci., 57(1): 95-101

Gommers, F. J. (1981). Biochemical interactions between nematodes and plants and the irrelevance to control:A review. Helminthological Abstracts (B), 50: 9-24

Goswami, B. K. and Vijayalakshmi, V. (1986). Nematicidal properties of some indigenous plant materials against rootknot nematode Meloidogyne incognita on tomato. Indian J. Nematol., 16: 65-68

Goyal, R., Chhabra, B. R. and Kalsi, P. S. (1990). Three oxygenated alantolides from Inula racemosa. Phytochemistry, 29(7): 2341-2343

Hong, L., Guohong L., Zhou, W., Wang, X. and Zhang, K. (2007). Screening and isolation of a nematicidal sesquiterpenes from Magnolia grandiflora L. Pest Manag. Sci., 63: 301-305

Iruthaya, K. and Devraj, A. (2011). Effect of root exudates of Tagetes sp. on egg hatching behavior of Meloidogyne incognita. IRJP, 2(10): 93-96

Kalsi, S., Goyal, R., Talwar, K. K. and Chhabra, B. R. (1989). Stereostructures of two biologically active sesquiterpene lactones from Inula racemosa. Phytochemistry, 28: 2093-2096

Kataria, D. and Chahal, K. K. (2013).Chemistry and antifungal potential of alantolides from Inula racemosa $\mathrm{H}$. $J$. Chem. Sci., 125(1): 187-191

Khare, C. P. (2007). Indian Medicinal Plants: An Illustrated Dictionary. Springer-Verlag, Berlin, Heidelberg.

Lauro, L. and Rolih, C. (1990). Observations and research on an extract of Inula viscosa. Bollettinodella Societa Italiana di Biologia Sperimentale, 66: 829-834

Liu, C. H., Mishra, A. K. and Tan, R. X. (2006). Repellent, insecticidal and phytotoxic activities of isoalantolactone from Inula racemosa. Crop Prot., 25: 508-511

Ma, Y. Y., Zhao, D. G. and Gao, K. (2013). Structural investigation and biological activity of Sesquiterpene lactones from the traditional Chinese herb Inula racemosa. J. Nat. Prod., 76(4): 564-570

Mahajan, R., Singh, P., Bajaj, K. L. and Kalsi, P. S. (1986). Nematicidal activity of some sesquiterpenoids against root-knot nematode (Meloidogyne incognita). Nematologica, 32: 119-123

Marongiu, B., Piras, A., Pani, F., Porcedda, S. and Ballero, M. (2003). Extraction, separation and isolation of essential oils from natural matrices by supercritical $\mathrm{CO}_{2}$. Flavour Frag. J., 18: 505-509

Moerman, D. E. (1986). Medicinal plants of native America. University of Michigan AnnArbor., Museum of Anthroplogy. Technical report 19: II. 
Moosavi, M. R. (2012). Nematicidal effect of some herbal powders and their aqueous extracts against Meloidogyne javanica. Nematropica, 42: 48-56

Nimbalkar, R. S. K. and Rajurkar, S. K. (2009). Effect of plant root extracts to control root-knot nematode (Meloidogyne spp.) of soybean (Glycine max). BFAIJ1, (1): $65-68$

Noling, J. W. and Becker, J. O. (1994). The challenge of research and extension to define and implement alternatives to methyl bromide. J. Nematol., 26: 573-586

Oka, Y., Ben-Daniel, B. H. and Cohen, Y. (2006). Control of Meloidogyne javanica by formulations of Inula viscosa leaf extracts. J. Nematol., 38(1): 46-51

Oka, Y., Ben-Daniel, B. H. and Cohen, Y. (2001). Nematicidal activity of powder and extracts of Inula viscosa. Nematology, 3: 735-742

Oka, Y., Nacar, S., Putievsky, E., Ravid, U., Yaniv, Z., and Spiegel, Y. (2000). Nematicidal activity of essential oils and their components against the root-knot nematode. Phytopathology, 90: 710-715

Onifade, A. K. and Egunjobi, O. A. (1994). Suppression of Meloidogyne incognitapopulations with water hyacinth and water lettuce in Nigeria. Afro-Asian Journal of Nematology, 4: 96-100

Perez, M. P., Navas-Cortes, J. A., Pascual-Villalobos, M. J. and Castillo, P. (2003). Nematicidal activity of essential oils and organic amendments form Asteraceae against root-knot nematodes. Plant Pathol., 52: 395-401

Renco, M., Sasanelli, N. and Maistrello, L. (2014). Plants as natural sources of nematicides. In: Nematodes.Nova Science Publishers, Inc. Pp. 115-142

Sarin, Y. K. (1996) Illustrated Manual of Herbal Drugs used in Ayurveda. National Institute of Science Communication (CSIR), Dr. K. S. Krishnan Marg. New Dehli, India.
Seca, A. M. L., Grigore, A., Pinto, D. C. G. A. and Silva, A. M. S. (2014). The genus Inula and their metabolites from ethnopharmacological to medicinal uses. J. Ethnopharmacol, 154(2): 286-310

Serfoji, P., Rajeshkumar, S. and Selvaraj, T. (2010). Management of root-knot nematode, Meloidogyne incognita on tomato cv Pusa Ruby by using vermicompost, AM fungus, Glomus aggregatum and mycorrhiza helper bacterium, Bacillus coagulans. IJAT, 6(1): 37-45

Shabir, P. A., Nawchoo, I. A. and Wani, A. A. (2010). Development of vegetative and sexual multiplication protocol for commercialization of Inula racemosa Hook. f. -a critically endangered medicinal plant of N. W. Himalaya. Nat. Sci., 8: 246-252

Singh, S., Singh, B. and Singh, A. P. (2015). Nematodes: A threat to sustainability of agriculture. Procedia Environ. Sci., 29:215-216

Trudgill, D. L. and Block, V. C. (2001). Apomistic, polyphagus root-knot nematode. Ann. Rev. Phytopathol., 39: 53 $-77$

Ulubelen, A., Öksüz, S. and Gören, N. (1987). Sesquiterpene acids from Inula viscosa. Phytochemistry, 26: 1223 1224

Wang, K., Liu, H., Zhao, Y., Chen, X., Hu, Z., Song, Y. and $\mathrm{Ma}, \mathrm{X}$. (2000). Separation and determination of alantolactone and isoalantolactone in traditional Chinese herbs by capillary electrophoresis. Talanta, 52:10011005

Wollenweber, E., Mayer, K. and Roitman, J. N. (1991). Exudate flavonoids of Inula viscosa. Phytochemistry, 30: 2445-2446

Wu, H., Wu, H., Wang, W., Liu, T., Qi, M., Feng, J., Li, $\mathrm{X}$. and Liu, Y. (2016). Insecticidal activity of sesquiterpene lactones and monoterpenoid from the fruits of Carpesium abrotanoides. Ind. Crops Prod., 92:77-83 